\title{
Supply Chain Integration and Customer Relationship Management in the Airline Logistics
}

\author{
Muhammad Alshurideh ${ }^{1,2}$, Nizar M. Alsharari'3, Barween Al Kurdi ${ }^{4}$ \\ ${ }^{1}$ School of Business, The University of Jordan, Amman, Jordan \\ ${ }^{2}$ College of Business Administration, Fujairah University, Fujairah, UAE \\ ${ }^{3}$ Business Department, Higher Colleges of Technology, Sharjah Men's College, Sharjah, UAE \\ ${ }^{4}$ Marketing Department, Faculty of Business, Amman Arab University, Amman, Jordan \\ Email:mtraji@yahoo.com
}

How to cite this paper: Alshurideh, M. Alsharari, N.M. and Al Kurdi, B. (2019) Supply Chain Integration and Customer Relationship Management in the Airline Logistics. Theoretical Economics Letters, 9, 392-414.

https://doi.org/10.4236/tel.2019.92028

Received: December 11, 2018

Accepted: February 24, 2019

Published: February 27, 2019

Copyright (c) 2019 by author(s) and Scientific Research Publishing Inc. This work is licensed under the Creative Commons Attribution International License (CC BY 4.0).

http://creativecommons.org/licenses/by/4.0/

\begin{abstract}
This paper aims to explain the relationship between supply chain integration (SCI) and customer relationship management (CRM) in the Emirates airline (EA) logistics. The paper adopts qualitative research methodology and presents an interpretive case study approach. The study uses triangulation method of data collection including interviews, observations, and documents and archival records. This study can be considered as one of important studies because it links between logistics and airlines management in the emerging economy. It provides a model for an aspiring company to strategically manage customer relationships and shows that good CRM can promote business growth, customer retention, and revenues generation. The study provides important implications for both academics and practitioners alike through the implementation of CRM to gain a competitive advantage over their rivals. The study concludes that the ability to promote the operating leverage, innovation, and entrepreneurship ideas, as well as a visionary management team, is essential for EA. It also concludes that the process of SCI can be improved from internal logistics processes to external integration with suppliers and customers, and such integration can be achieved via the CRM system. The study recommends that airlines industry need to make strategic efforts to be more competitive in the supply chain core of business by reducing logistics costs and satisfying the needs of their customers.
\end{abstract}

\section{Keywords}

Supply Chain, Emirates Airline, Customer Relationship Management, Airline Logistics 


\section{Introduction}

Globalization of the world economy is forcing multinational corporations to integrate the global airline industry with their international logistics and transport systems. To compete in this dynamic marketplace, multinational corporations must recognize their core competencies and outsource their logistics value-added activities to third-party logistics providers [1]. Thus, the movement of passengers to different parts of the globe involves various service parties [2] [3]. Given that, such a situation obviously increases the risk of interruptions or shutdowns of supply chains, the development of multiple initiatives to enhance supply chain security without adversely affecting efficiency has become an important issue for these multinational corporations [3] [4] [5] [6] [7] and international service providers, such as Emirates airline (EA).

The airline industry is the main actor for enhancing international trade in products and unfinished goods [8]. In particular, in the case of Dubai, which is an island city in the United Arab Emirates (UAE), total volume, as measured by tons and number of passengers, accounted for more than 70 million passengers in 2015 [9]. At the same time, global trade liberalization has facilitated the development of maritime logistics. The aviation industry has faced both supply uncertainty and acceleration in customer service demand due to a turbulent and competitive global economy [10]. Customer need for a wider array of global services necessitates better-integrated airline services. Within a dynamic environment, airline companies play a fundamental role in satisfying customer requirements (e.g., passengers, shippers and consignees) through effectively deploying fleets and selecting airports. Within this atmosphere, airline companies need to make strategic efforts to be competitive in the supply chain by reducing logistics costs and satisfying the needs of customers [2] [8] [11] [12] [13] [14] [15]. These companies can achieve strategic collaboration with supply chain partners by adopting new customer management systems, especially Customer Relationship Management (CRM).

CRM has become the current topic for many practitioners and scholars [16]. Increasingly, airline companies are adopting customer-centric strategies, programs, tools, and technology for efficient and effective management of customer relationships. They realize the need for in-depth and integrated customer knowledge to build close and cooperative partnering relationships with their customers to increase repeat buying and the mutual relationship becomes economically valuable [17] [18] [19] [20] [21]. The emergence of a new channels and technologies is significantly altering how companies interface with their customers, development bringing about a greater degree of integration between marketing, sales, and customer service functions in organizations. For practitioners, CRM represents an enterprise approach to full knowledge of customer behavior and preferences and development of programs and strategies that encourage customers to continually enhance their business relationship with the company [16]. 
Emirates is a one of the biggest companies in the worldwide airline industry, but today there are a large number of airline companies still expanding and seeking to steal market share from existing airlines. In this growing industry, there are more and more choices. The customer can choose the airline they want to travel with and still look for the one, which can serve their immediate need. To maintain their business success and acquire customers (passengers) to fly with them, the airlines need to modify their strategies and services, which make customers see the difference and added value once purchasing their products such as, airline tickets and travel amenities [22]. EA started using a CRM strategy in 2000. Before that, Emirates did not use any CRM software or strategies. Emirates has repositioned its market by formulating a global marketing strategy that represents its customers as globalists. The company launched a global multimedia campaign named Hello Tomorrow that aimed to position the airline as an enabler of global connectivity and significant experiences. The successful performance of EA refers to world-class award: Winner of Skytrax 2016, which is World's Best Airline award. Therefore, this paper aims to explain the relationship between Supply Chain Integration (SCI) and Customer Relationship Management (CRM) in the Emirates Airline (EA).

\section{Conceptual Framework}

\subsection{Supply Chain Integration (SCI) and CRM Systems}

SCI refers to coordination mechanisms that should be streamlined and interconnected both within and outside the boundaries of a company [23]. The traditional approach of logistics integration focuses on functional boundaries within a company [24], whereas a recent approach of logistics integration expands the scope of integration, transcending company boundaries along the entire supply chain. [25] [26] [27] [28] and [29] have defined SCI as the strategic collaboration of both intra- and extra-organizational actors.

SCI in the airline industry involves a network of passengers, shippers, freight forwarders, shipping carriers, logistics service providers, and agents who perform various value-added activities, usually sequentially, to add value for consumers. Regarding horizontal integration, airline alliances and cooperation continue to play a central role in the operation and long-term viability of airline companies. Numerous airlines have undertaken vertical integration, diversifying operations and services into various components throughout a multimodal supply chain system [31] [32]. [32] suggested that empirical investigation of the strategy-performance relationships related to such integrations is needed. Research has indicated that an increasing demand for integrated logistics and transport service renders maritime transport and airport operation inseparable from logistics and supply chain management [33]. Consequently, an emerging trend in liner shipping is integration and diversification into inland transport, terminal operation, and logistics [30] [32].

Supply chain orientation is a management philosophy, and supply chain 
management is the total of all the overt management actions undertaken to realize the benefits of that philosophy [34]. Integration has been crucial in logistics and supply chain management since the 1980s. SCI refers to the strategic collaboration with supply chain partners and cooperative management of Intra- and inter-organizational processes to build and maintain a seamless channel for the precise and timely flow of decisions, information, materials, finished goods, and services to the eventual customers [30] [35] [36] [37] [38]. [39] and [30] assert that the SCI process should progress from integration of internal logistics to external integration with suppliers and customers, and such internal and external integration can be accomplished through a CRM system [40].

CRM is a strategy for managing all the company's relationships and interactions with its customers and potential customers; it helps to improve profitability [41]. CRM enables the organization to focus on relationships with individual people-whether those are customers, service users, colleagues, or suppliers. Some of the biggest gains in productivity can come from moving beyond CRM as a sales and marketing tool and embedding it in the business-from HR to customer service and supply-chain management [41] [42]. The core theme of all CRM and relationship marketing perspectives is a focus on cooperative relationships between the company and its customers, and other marketing actors. [43] have characterized such cooperative relationships as being interdependent and long-term oriented rather than being concerned with short-term, discrete transactions.

Another important facet of CRM is customer selectivity. As several research studies have shown, not all customers are equally profitable for an individual company [44]. The company, therefore, must be selective in tailoring its programs and marketing efforts by segmenting and selecting appropriate customers for individual marketing programs. In some cases, the outsourcing of some customers can be defined as how a company allocates its resources to those customers it can serve the best to create mutual value. However, the objective of a company is not really to prune its customer base but to identify the programs and methods that would be the most profitable as it creates value for the company and the customer [44] [45]. Hence, some researchers define CRM as follows:

[CRM is a] comprehensive strategy and the process of acquiring, retaining and partnering with selective customers to create superior value for the company and the customer. It involves the integration of marketing, sales, customer service, and the supply-chain functions of the organization to achieve greater efficiencies and effectiveness in delivering customer value [46].

As indicated in the above definition, the purpose of CRM is to improve marketing productivity. Marketing productivity is achieved by increasing marketing efficiency and by enhancing marketing effectiveness [47] [48]. CRM has some advantages and disadvantages. On the one hand, advantages can be summarized as follows [41] [42]: CRM helps companies get insights into their sales activities, marketing activities, and customer support activities. CRM solutions are espe- 
cially useful in companies that have high purchase frequency/customer transactions. CRM helps in identifying profitable/unprofitable customers, regular vs. one-time customers, etc. So that companies can utilize more resources for important customers; it enables the organization to analyze and follow reports; it provides effective time management as CRM prompts users to follow up on activities and delivers automated alerts when important events occur, or if actions are missed. CRM integrates with finance, accounting, and other back-office applications to connect processes and remove double handling of tasks. The biggest benefit of CRM systems is that their use leads to a better overall customer experience.

In contrast, the following disadvantages have been identified by [41] [42] as: CRM may result in duplication of tasks, if not all the related enterprise applications are integrated; if the CRM software is too complex and challenging to understand, not all of its functionalities may be utilized; return on investment (ROI) can be difficult to establish (and difficult to measure) with a CRM application, especially in the short run; educating the users about proper CRM usage, and getting them to actually use it, might be a challenge; easy to use interfaces and appropriate help functions plus customers and employees' training and development are crucial for successful CRM implementation [49] [50]; scalability may either be limited or too costly, which deters companies from providing access to CRM for all potential users; the cost of the software and customization is generally considered high; if the CRM solution is not customized to the business objectives of a particular company, implementation might fail.

\subsection{Types of CRM}

CRM itself is not a new concept but is now practical due to recent advances in enterprise software technology. An outgrowth of sales force automation (SFA) tools, CRM is often referred to in the literature as one-to-one marketing [51]. Based on this, four major types of CRM were identified: strategic CRM, operational CRM, analytical CRM and collaborative CRM.

\section{Strategic CRM}

Strategic CRM is a type of CRM in which the customer comes first in the eyes of the business. It collects, segregates, and applies information about customers and market trends to come up with better value propositions for the customer. The business knows the purchasing behavior of the customer-a happy customer purchases more frequently than other customers. This means that any business not considering strategic CRM risks losing market share [52].

\section{Operational CRM}

Operational CRM is oriented towards customer-centric business processes, such as marketing, selling, and services. It includes three automation: sales force automation, marketing automation, and service automation [52].

\section{Analytical CRM}

Analytical CRM is based on capturing, interpreting, segregating, storing, modifying, processing, and reporting customer-related data. It also contains in- 
ternal business-wide data, such assales data (products, volume, and purchase history), finance data (purchase history, credit scores) and marketing data (response to campaigns, customer loyalty programs). Base CRM is an example of analytical CRM. It provides detailed analytics and customized reports [52]. Analytical CRM can set different selling approaches to different customer segments. Also, different content and styling can be offered to different customer segments. For the customers, analytical CRM gives customized and timely solutions to problems. For the business, it provides sales prospects and improves customer acquisition and retention [18] [20] [52] [53].

\section{Collaborative CRM}

Collaborative CRM is an alignment of resources and strategies among separate businesses for identifying, acquiring, developing, retaining, and maintaining valuable customers. Collaborative CRM enables smooth communication and transactions among businesses. Though traditional ways of communication, such as airmail, telephone, and fax, are still used, collaborative CRM employs new communication systems, such as chat rooms, web forums, Voice over Internet Protocol (VoIP), and Electronic Data Interchange (EDI) [52] [54].

\subsection{CRM Implementation Issues}

Many scholars, who study buyer-seller relationships, have discussed various aspects of the relationship development process [43] [55] [56]. One of these aspects of CRM development is the multitude of customer interfaces that a company has to manage in today's world. Until recently, a company's direct interface with customers, if any, was primarily through sales people or service agents. In today's business environment, most companies interface with their customers through a variety of channels, including sales people, service personnel, call centers, Internet websites, marketing departments, fulfillment houses, market and business development agents, and so forth. For large customers, it also includes cross-functional teams that may include personnel from various functional departments. Although each of these units could operate independently, they still need to share information about individual customers and their interactions with the company on a real-time basis. For example, a customer who just placed an order on the Internet and subsequently calls the call center for order verification expects call center staff to know the details of his or her order history. Similarly, a customer approached by a sales person who is unaware that the customer recently expressed dissatisfaction with customer service is not likely to respond kindly to the sales person [57] [58] [59] [60] [61]. On the other hand, if the sales person were aware of the problem encountered by the customer-the complaint, and the action already initiated to resolve the complaint-the sales person would be in a relatively good position to handle the situation well. Therefore, effective CRM implementation requires a front-line information system that shares relevant customer information across all interface units. Relational databases, data warehousing, and data mining tools are very valuable for CRM systems and solutions [16]. 
The challenge is to develop an integrated CRM platform that collects relevant data input at each customer interface and simultaneously provides knowledge output about the strategy and tactics suitable to win customer business and loyalty. For instance, if call center personnel cannot identify and distinguish a high-value customer and do not know what to upsell or cross-sell to this customer, it could mean a remarkable opportunity lost. Although most CRM software solutions based on relational databases help to share customer information, they still do not provide knowledge output to the front-line personnel. As shown in Figure 1, the CRM solutions platform needs to be based on interactive technology and processes. It should help the company develop and enhance customer interactions and one-to-one marketing through the application of suitable intelligent agents that promote the front-line relationship with customers. Such a system would identify appropriate data inputs at each customer interaction site and use analytical platforms to generate appropriate knowledge output for front-line staff during customer interactions. In addition, implementation tools to support interactive solutions for customer profitability analysis, customer segmentation, demand generation, account planning, opportunity management, contact management, integrated marketing communications, customer care strategies, customer problem solving, virtual team management of the major global accounts, and measuring CRM performance would be the next level of solutions sought by most enterprises [16].

During the implementation of CRM solutions, some companies seem to inappropriately supervise the basic considerations that would make such initiatives successful. Since CRM implementation comprises a significant information technology (IT) component, these companies have often handed over responsibility for CRM implementation to IT departments. In this way, they become focused only on installing CRM software solutions without developing a CRM

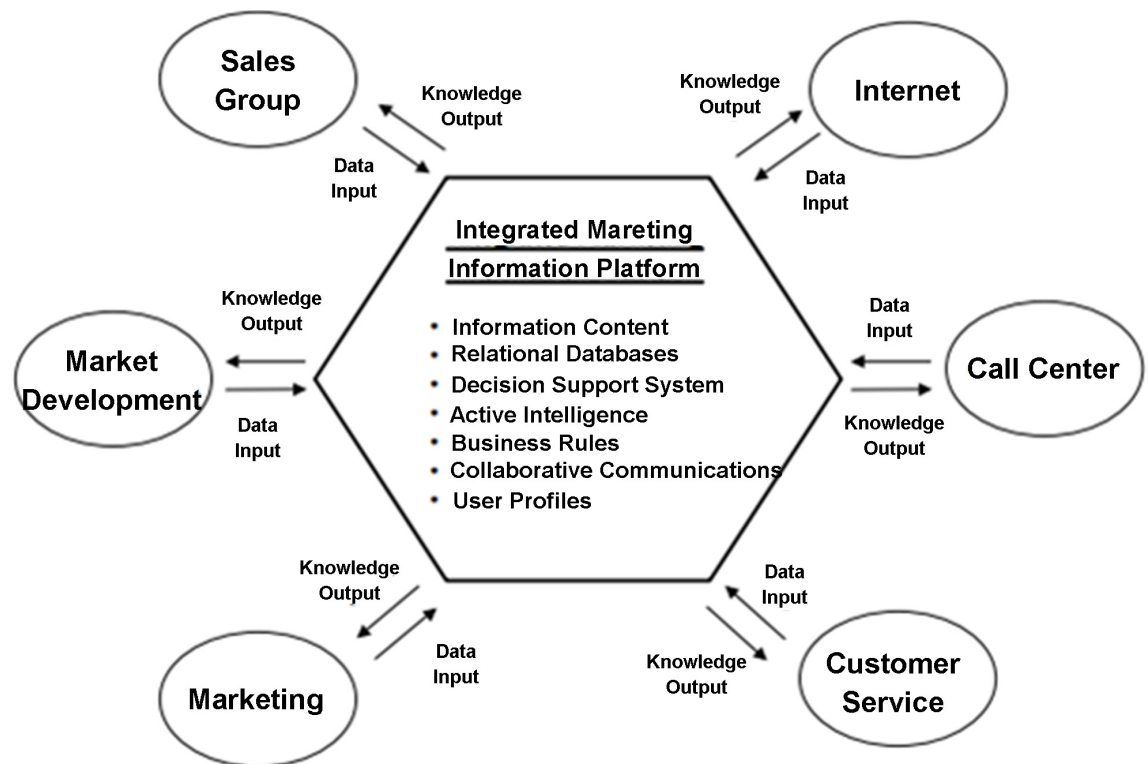

Figure 1. Data Model/Information Platform for CRM. Source: [16]. 
strategy or program. This leads to creating a working tool within the company, but the usability and effectiveness in producing desirable results from such tools can be limited. CRM tools are valuable when they are used to identify and differentiate individual customers and to generate individualized offers and fulfill customized solutions. The lack of a CRM strategy or CRM programs would leave the front-line people without any knowledge of what they should be doing with the additional customer information that they now have access to. Those applying themselves and developing improvised solutions could find that their informal solutions backfire and cause unintended deterioration in customer relationships. Hence, it is important to consider the CRM process framework in its totality. CRM tools are intended to supplement a company's strategy for building effective customer relationships. Appropriate strategy and excellent implementation are both needed for obtaining successful results [16]. The following sections explain the implementation process of CRM supported by Enterprises Resource Plan (ERP) data.

\subsection{ERP and CRM}

Enterprises Resource Plan (ERP), when successfully implemented, links all areas of a company, including order management, manufacturing, human resources, financial systems, and distribution, with external suppliers and customers in a tightly integrated system with shared data and visibility [62]. Major enterprise systems vendors, who have been successful in the ERP market, are gearing up for the growing needs of CRM by aggressively forming alliances with, or taking over other software companies that have been operating in the CRM market. For example, J.D. Edwards entered into a deal with Seibel, a leading CRM company, in May 1999 and subsequently shut down its in-house sales force automation team. PeopleSoft acquired Vantive's CRM software in October 1999 to integrate with its ERP systems (See [63]). Through SAP initiatives, users of SAP R/3 system can add Web-based CRM and SCM functions while leaving the core R/3 system intact [64].

Oracle has taken the most drastic steps in forming a new bond between ERP and CRM. The new flagship ERP/CRM software package, called 11i, is heavily Internet-oriented and allows users to seamlessly implement modules of CRM with a smaller ERP suite. Significant differences exist between ERP technology and CRM applications. ERP serves as a strong foundation with tightly integrated back office functions, while CRM strives to link front and back office applications to maintain relationships and build customer loyalty [64] [65].

ERP systems promise to integrate all functional areas of the business with suppliers and customers. CRM promises to improve front office applications and customer touch points to optimize customer satisfaction and profitability [63] [66]. While ERP systems address fragmented information systems, CRM addresses fragmented customer data. CRM applications are Web-enabled and designed to extend the data mining capabilities of ERP throughout the supply chain to customers, distributors, and manufacturers [67]. Organizations can use 
CRM analytical capabilities to predict and answer key business questions on customer intelligence and share the results across channels. Although ERP is not required for CRM, providing customers, suppliers, and employees with Webbased access to systems through CRM will only be beneficial if the underlying infrastructure, such as data warehouses and ERP, exists [68]. Companies with an ERP system, however, need to understand where they are in the implementation process, as well as assess where other technologies, such as data warehouses, fit in before plunging into CRM applications [64] [69].

\section{Research Methodology}

This paper presents a case study of EA to explain the implementation of CRM and clarify the types of CRM that Emirates uses. The author's relevant professional experience, extensive literature review, and communications with selected personnel of EA provided the foundation for this paper. Selection of the case study methodology was based on the following reasons: the ability of this methodology to help the researcher study the problem within its real environment [70]; the extent of control an investigator has over actual behavior; and the degree of focus on contemporary as opposed to historical events [71].

To ensure the quality of information gathered in the case study and the collection of required data, a case study protocol was developed with the following sections: the aim of the study, issues to be addressed, case study sites, sources of information, categories of questions, other potential sources of information, and format of the narrative [72]. Data were collected using interviews, observations, documentation, and archival records. Interviews were organized as unstructured and in-depth. Fifteen people were interviewed. The selection of interviewees was based on their involvement in the CRM implementation process in the following roles: member of top management, CRM committee/teamwork member, accounting manager, marketing manager and IT manager.

Since the research aim was to explain the CRM implementation process within EA, a qualitative research plan took the form of an interpretive case-study to track different paths of change and their effects over time [73]. The authors were able to reconstruct the historical context of EA, based on documentary evidence, historical data, and interviews with managers (and others), who worked during the pre-implementation and post-implementation phases of the new CRM system. To enhance the validity of the research results, this study uses the triangulation method of data collection: interviews and observations as primary evidence, and documents and archival records as secondary evidence. This approach has been used by many authors [74] [75] [76].

The study employed mainly the qualitative approach to collect the study required data. Fifteen interviews have been executed. The interviews were determined through a set of sequences of employees who involved in planning the loyalty schemes that offered by Emirate Airline. The interviews were prepared and executed according to the targeted interviewees conveniently. The needed data has been collected through transcript, coded and analyzed the data recorded 
from the interviews. To avoid the bias, the transcribed data from interviews has been reviewed by other scholars to verify the coding process. More than $90 \%$ of the elected themes has been chosen and validated. Based on [77] and [78], qualitative data has been collected by following a set of steps. Firstly, the study main items were determined and given specific codes to be used as seen in Table 1.

Secondly, the interviews were recorded and transcript. Thirdly, the researchers went through the texts and by themes the important and relevant words and statements had been defined and coded according the study constructs. Such relevant and selected phrases have been converted by meaning into codes fit with the study items. Then the elicited themes were grouped and their frequencies were counted. The interviews approach was used for a set of reasons. Initially, it represents the convenient approach to be used in such situations especially with loyal travelers [79] [80]. Also, such method is representing a good technique to collected needed data when specific opinions are important to be explored and fit properly for the study purposes [81] [82]. The data has been collected from customers in UAE through conducted interviews which lasted between 30 to 40 minutes for each of them. Such interviews have been guided by the researchers to cover the main study themes and constructs. The interviews questions have been prepared by the researchers and reviewed by other scholars who acknowledge applying the loyalty programs within the airlines industries to check their appropriateness.

The way that followed in analyzing the texts is guided by [17] [83] [84]. The process of analysis began at the same time as the data were collected and prepared for analysis. Accordingly, [1] interviews were recorded and transcribed progressively by using a word-processing software and such process of analysis commenced with the full transcript of all interviews. These transcripts were entered and coded in the software through reading and re-reading data many times, paying special attention to the mode of expression (e.g. intonation, pauses, etc.). This helped the author to recognize the particular issues that resulted from each interview about other evidence [85] [86]. Thus, data reduction took place when common sequences and patterns were spotted and highlighted. For example, when the interviewee mentioned that I'm happy using the loyalty program card-I feel privileged by the company and feel happy. Such statements were coded within SCI counter. All texts were transcribed following the same method to accurately capture all incidents that are elated to the study elements. Afterward, similar themes were grouped and classified as seen in Table 2. Meanwhile, the detection of any differences in perceptions among interviewees that might contradict the patterns previously identified was closely managed. In this regard, similar themes or opinions expressed by the interviewees were explained within the normal body of discussion and analysis, while different themes were discussed using direct quotations from the interviewees [87] [88]. These procedures were followed to guarantee the plausibility of the analysis and 
Table 1. A summary of study factors and related codes.

\begin{tabular}{ccc}
\hline No. & Codes & Study items \\
\hline $1-$ & OE & Organizational Efficiency \\
$2-$ & SCI & Supply Chain Integration \\
$3-$ & CL & Customers Loyalty \\
$4-$ & BS & Business Strategy \\
\hline
\end{tabular}

Source: Authors.

Table 2. The study constructs' incidents frequencies.

\begin{tabular}{cccc}
\hline No. & Codes & Study items & Incidents Frequencies \\
\hline $1-$ & OE & Organizational Efficiency & 247 \\
$2-$ & SCI & Supply chain integration & 203 \\
$3-$ & CL & Customers Loyalty & 199 \\
$4-$ & BS & Business Strategy & 178 \\
\hline
\end{tabular}

Source: Authors.

the authenticity of the study findings. Table 2 summarized the final study constructs' incidents frequencies.

The scholars tried to find the relationships and correlations among the study variables by linking texts segments that have same meaning or affect each other. By this, there is a try to link between the qualitative data and quantitative data by looking for any cause-effect relationships. In a way to find such links among the study codes by themes and based on the above frequencies, it has been found that the CRM implementation is rely mainly on a set of determinants which are reported based on their importance as: Organizational Efficiency, SCI, Customers Loyalty and Business Strategy. The following Diagram explains the relationships among the study constructs (Figure 2).

\section{Case Study: Emirates Airline (EA)}

\subsection{Historical Background}

In the early 1970s, the rulers of the UAE established a common flag carrier called Gulf Air with a few Gulf Cooperation Council (GCC) countries. However, a tense relationship between Gulf Air and the Dubai Government existed from the beginning. The Dubai Government declined to agree to Gulf Air's demands to abandon its open skies policy. In reaction, Gulf Air reduced frequencies and capacities to and from Dubai by more than two-thirds between 1984 and 1985 without notice to the Dubai Government Authorities. Since other foreign carriers operating to Dubai proved unable or unwilling to fill the gap, Dubai's then ruler, Sheik Maktoum bin Rashid Al-Maktoum, assembled a team of experts to develop an emergency plan to set up a home carrier for Dubai. The ruler accepted the team recommendations, but he imposed two conditions: the new 


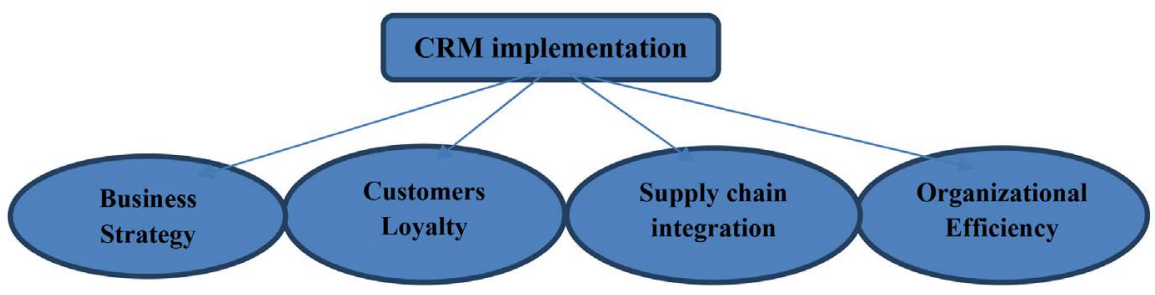

Figure 2. CRM implementation framework. Source: Authors.

airline should meet the highest quality standards, and there would be no additional capital injections from the government other than the agreed startup capital of US\$10 million. Emirates was incorporated, with limited liability, by an Amiri decree issued by the ruler on 26 June 1985 and is wholly owned by the Investment Corporation of Dubai, a Government of Dubai entity. On 25 October 1985, Emirates' first flight took off and crossed the skies of the UAE. Despite the global crises, which influenced the aviation industry in the dawn of a new millennium, and strong influences from other external factors, Emirates has continued a steady annual growth rate and has never reported a loss since its renaissance in 1985 [22]. The following history highlights EA's progress:

$\Rightarrow$ 1984: Sheikh Mohammed bin Rashid Al Maktoum makes the decision to build an airline in Dubai, using the services of data (Dubai National Air Transport Association), which was already the sales agent for 25 airlines.

$\Rightarrow$ 1985: The airline's first flight, flight EK600, is Dubai-Karachion 25 October 1985.

$\Rightarrow$ 1991: Emirates finally gets a slot at the busiest international hub in the world-London's Heathrow Airport. Moreover, as the airline celebrates its sixth anniversary, 25,000 passengers a week are being flown to 23 destinations.

$\Rightarrow$ 1993: Emirates becomes the first airline to introduce telecommunications on an Airbus-in all three classes.

$\Rightarrow$ 1998: Emirates is votedBest Airline in the Worldat the prestigious OAG Awards.

$\Rightarrow$ 2008: Terminal 3 was officially opened for the use of Emirates. Emirates becomes the first international carrier to introduce an in-flight mobile phone service.

$\Rightarrow$ 2014: Emirates is named the Skytrax world's Most Valuable Airline Brand.

\subsection{Current Leadership}

Emirates has developed its vision and values as follows: A strong and stable leadership team, ambitious yet calculated decision-making, and ground-breaking ideas all contribute to the creation of great companies. Of course, these have played a significant part in the development and growth of Emirates, and it is believed that business ethics and customer focus are the foundations on which the success has been built [89] [90]. Strong brand awareness through sponsorship of sports and games, caring for their employees and stakeholders, as well as 
the environment and the communities Emirates serve, have played a huge part in its past and will continue to signify its future. Emirates, like most global enterprises in the region, maintains a narrow ownership structure. Emirates' President-Tim Clark-oversees the entire aviation business and reports to the executive vice chairperson of the entire Emirates Group, Maurice Flanagan. He is also in charge of the central carrier operations: the freight business, Emirates Sky Cargo, the frequent flyer program (Skywards), airport services, and, also, the growing hotel and holiday travel business. The unique organizational structure of the Emirates Group-aflat hierarchy-has been a great help for its growth and development and is considered a major strength for Emirates. This structure allows for clear communication and rapid decision-making at a senior level [22].

\section{The Discussion and Managerial Implications}

\subsection{Managerial Implications}

Emirates is an international airline based in Dubai, UAE. The airline is a subsidiary of The Emirates Group, which is wholly owned by the Investment Corporation of Dubai (a government holding company). It is the largest airline in the Middle East, operating over 3000 flights per week from its hub at Dubai International Airport, to more than 130 cities in 77 countries across six continents. Cargo activities are undertaken by the Emirates Group's Emirates Sky Cargodivision. Emirates has built up a strong brand name as a leader in the aviation industry, particularly regarding service excellence. Emirates has won numerous awards-it was ranked 8th by Air Transport World for Airline of the Yearin 2012. The award is based on recognition of its commitment to safety and operational excellence, customer service trendsetters, and financial condition, including a 25 -year consecutive annual profit. Emirates is rated as a four-star airline by aviation consultancy group Skytrax. Emirates has won the prestigious title of World's Best Airlinein Skytrax's World Airline Awards in 2016 [91].

Dubai is located at a central point between East and West. Consequently, EA is capable of tapping resources from both sides. Since the densely populated and fastest growing economies of the world, namely, China and India, are within close reach of Dubai, the scope of Emirates' operations to these countries and the region has substantially increased in recent years. In general, the Asian continent is witnessing an economic boom and the airline has benefited from this opportunity. In 2010, Emirates operated over 2400 passenger flights per week to 105 cities in 62 countries across six continents. It has over 28,000 employees, including 13,000 cabin crewmembers of more than 120 nationalities capable of conversing in 60 different languages. Emirates is renowned for creating market trends and pioneering new ideas, often in contrast to the conventional industry's view, and several important services, including personal entertainment systems in all seats, private first-class suites, use of mobile phones on board, and the introduction of Smart-Landing and Smart-Runway safety solutions. Recently, Emirates introduced CRM in conjunction with Oracle's ERP software to manage 
and maintain their relationships customers. CRM Project Manager explained:

Emirates airline considered implementing CRM as supported by ERP in the early 2000s. Before the CRM, Emirates had nothing to do with the customers, only they come and go without any benefits. After that the airline decided to implement CRM to make sure that the customers are fully satisfied and to form a trust relationship between them so that they can be a frequent customer on Emirates, and by doing that both the airline and the customer wins. Emirates has considered implementing the Windows 8 CRM or so-called KIS and the loyalty program.

\subsection{Implementation of CRM}

Emirates implemented CRM successfully as a system for managing the company's interactions with current and future customers. The CRM system consists of three elements: sales force automation, customer service, and marketing automation. At the same time, Emirates developed three types of CRM: strategic, operational, and analytical. The Manager of Aeronautical Services \& ATM Emirates clarified implementation in this way:

CRM has successfully integrated various aspects of customer relations: Cooperation, Communication, Coordination, and Collaboration from all organizational employees. This implementation was supported by the airline's top management. Emirates airline was the first company in the Middle East to use CRM software (KIS). CRM describes a company-wide business strategy including customer-interface departments as well as other departments.

Implementation of CRM has included different customer options, mainly the Windows 8 CRM and the loyalty program. Other CRM implementations include E-Services tools, such as E-Claims, E-Services guide tour, and E-Newsletter. Extra airline passenger benefits include special meals, chauffeur-driven cars, Microsoft Fast Track, Dubai visa service, stopover service, hotel booking functionality, and unaccompanied young passengers.

\subsection{Windows 8-Based CRM}

Emirates has created its Windows 8 based CRM application on an HP Elite-Pad 900 tablet computer. It began rolling out the tablets on planes in 2012. Accordingly, for several years, it has run a CRM app, and it was developed for laptops, but by making the program accessible on a tablet, flight crews will have an easier time concentrating on customer experience, according to an Emirates vice president of communications, who stated:

By making this so much easier, we will get so much more information on what we do right. Until 2004, an Emirates purser, or chief crew officer, had recorded flight notes with pen and paper. Then, Emirates airline created its business application, Knowledge-driven In flight Service (KIS), which allows pursers to use laptops to take stock of what transpired on a flight and how to better serve passengers. 
Emirates used a specific CRM database, which runs during the flight to maintain a profitable long-term relationship with their customers by delivering satisfaction. It has started rolling out in-flight Windows 8 tablets that enable cabin crew to access core CRM and HR information to improve customers' services. In this regard, the Senior Vice-President for Cabin Crew said:

There is a lot of noise of people doing things with tablet devices, but we are an airline of firsts. The airline first used tablets in 2004, starting with HP, then moving to Lenovo Windows-based tablets.

Emirates provided 1000 pursers with HP tablets as part of Knowledge-driven In-flight Service (KIS). It allows the airline's cabin crew to see which previous trips a passenger has taken with the carrier and based on this, knows their food, wine, and seating preferences, or any issues a customer had during their travels. Moreover, the gathered data support Emirates in segmentation and targeting because they can analyze very specific information about customers' expectations. This information is the key that supports Emirates' decision-making about adding and offering the right services to satisfy its customers' expectations. This system allows Emirates to provide more focused and personalized services. Pursers use KIS to brief the cabin crew before every flight and check passenger's special needs, as well as see who is enrolled in Emirates' frequent flyer program Skywards. This enables the crew to invest more in those loyal customers and to provide a more personalized service. Cabin crew can also use the KIS system to perform in-flight upgrades to Business or First Class, as well as post customer feedback that is emailed to headquarters upon landing. That is one of the most important sources of information that pioneers the competitive intelligence process and allows Emirates to improve its services and keep its customers loyal and satisfied.

\subsection{Loyalty Program Based CRM}

A loyalty program was implemented to satisfy customers by allowing them to save money and to gather personal information about those clients. It also created a lock-in system where the customer should remain with the same airline to benefit from discounts. It offers membership in two types of loyalty programs: Emirates Skywards and Business Rewards.

Emirates Skywards is the award-winning frequent flyer program launched in May 2000. Membership in the program provides access to many exclusive benefits designed to make travel more rewarding and enjoyable. Skywards is the number one CRM strategy of EA. Membership in Skywards gives the traveler or customer the chance to earn and spend accumulated Miles with Emirates and a wide selection of partners and enhances their travel experience with benefits and services that make every trip more rewarding. Every time you fly with Emirates, you earn Skywards Miles, even on a special fare. Skywards Miles are calculated using four basic inputs: route, fare type, class, and tier. Therefore, the customers can maximize their Miles income depending on what fare they choose and what class they fly in. Once they reach the Silver tier they also begin to collect addi- 
tional Miles based on their tier status. The more you fly, the more you earn Miles. The number of Miles you earn depends on the class you have chosen, on the destination, and the duration of the plane travel. The collected Miles are valid for three years. Emirates frequent flyer program has four rewarding membership tiers, starting with Blue and progressing through Silver and Gold to Platinum (see Figure 3).

Business Rewards is part of the loyalty program of Emirates, which is open to small and medium-sized enterprises (SMEs) around the world. Organizations earn Business Rewards Miles on flights taken by their employees, which can be spent on Rewards flights and upgrades. Up to 80 employees from an organization can be registered under a Business Rewards account, Individuals may be removed from an organization's Business Rewards account at any time, but no more than 80 new enrolments can be made within a 12-month period. To enroll into Business Rewards. First, the customer has to be a member of Emirates Skywards. To join, the customer has to choose an administrator in their company, and this person or administrator will initiate group or individual membership, by completing a travel account form, quoting the customer or employee business rewards, and ensuring that the employee is credited with the company Miles. With every Emirates flight, the organization will earn Business Rewards Miles and the individual will earn Skywards Miles, thereby giving benefits to both the employee and the organization. When an employee books a flight through the nominated travel agent or Emirates Contact Centre, they simply quote the employee's Business Rewards number to earn Business Rewards Miles. The traveler/employee/customer earns one Mile for each US dollar spent on the base airfare, before surcharges, taxes, and other industry partner charges (which are not included in Miles accrual). Miles are calculated at the end of each month for travel completed within the month. Miles are valid for three years from the date that they are earned. Emirates always make sure to satisfy their customers by providing them with benefits for every program in which they enroll. Each dollar spent earns one business reward mile, and they are eligible for special offers from Emirates' partners as well as attractive prices.

\section{Conclusions, Limitations and Future Research}

The study findings conclude that Dubai stands out as a global city and the business hub of the Middle East. It is also a major transport hub for passengers and cargo and, since EA is technical, a subsidiary of a private holding company and wholly owned by the Government of Dubai and is the official airline of Dubai, EA has become one of the main competitors and leaders in the international market.

The study concludes that EA provides a road map of how to develop CRM and relationship marketing. Part of EAs' strength and competitive advantage lies in its customer service orientation and SCI. They have developed an advanced CRM system that offers a comprehensive range of CRM and loyalty solutions, 


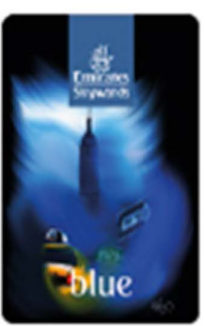

Blue

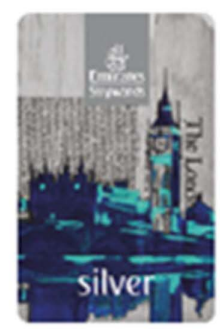

Silver

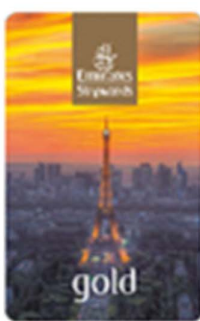

Gold

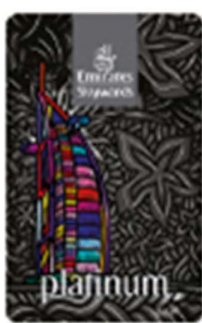

Platinum

Figure 3. Rewarding membership tiers. Source: [9] [91].

covering every step from conception, creation and design to delivery, implementation, management, and support. A customer is central to EAs' strength in the airline market. Customers are the ones who reflect the good or bad services of the company, whether they are fully satisfied or disappointed. EAs offer customers all they need during its operations and processes, as well as on the flights themselves, to keep customers happy.

It also concludes that EAs successfully implemented CRM as a system for managing the company's interactions with current and future customers. The implementation of CRM by EA has resulted in a positive change. EAs' operational strategies have always been successful. Implementing CRM in the company has been a major factor in achieving the goals of customer trust and satisfaction as well as developing an excellent reputation in the industry. The domain of CRM extends into many areas of marketing and strategic decisions. Building relationships with customers is a fundamental business for any enterprise, and it requires a holistic strategy and process to make it successful [92]. It has developed around the theme of cooperation and the collaboration of organizational units and their activity, and if the phenomenon of cooperation and collaboration with customers becomes the dominant paradigm of business practice and research, CRM has the potential to emerge as the dominant perspective of business. From the corporate implementation point of view, CRM should not be misunderstood to simply mean a software solution implementation project [16]. It's good to remind that this study has some limitations. A longitudinal study could not be conducted to observe the historical events unfolding over time. In the future, research on the barriers to implementing successful CRM strategies would be useful as well as empirical research on the impact of CRM on company performance. However, SCI has rarely been studied in the airline industry, despite the fact that this industry has two unique characteristics that differentiate it from manufacturing industries and, therefore, make a separate study of its SCI indispensable. First, while studies of SCI in manufacturing industries have concentrated only on supplier integration, in a service operation (e.g., airlines), partner integration (e.g., terminal operator) is also an important issue that can affect organizational performance. Second, the aviation environment is more complex than manufacturing regarding its global service characteristics.

Future researchers can consider this study as a starting point to establish healthy long term relationships with clients through developing E-loyalty pro- 
gram such as E-points system. Many E-loyalty programs can be adopted such as loyalty cards in order to attract customers' to repeat the buying of airline transportation services.

\section{Conflicts of Interest}

The authors declare no conflicts of interest regarding the publication of this paper.

\section{References}

[1] Alsharari, N.M. (2013) The Dynamics of Management Accounting Change in the Jordanian Customs Organization as Influenced by NPM Reforms. Institutional pressures, Doctoral Thesis, Durham University.

[2] Russell, D.M. and Saldanha, J.P. (2003) Five Tenets of Security-Aware Logistics and Supply Chain Operation. Transportation Journal, 44-54.

[3] Sheu, C., Rebecca Yen, H. and Chae, B. (2006) Determinants of Supplier-Retailer Collaboration: Evidence from an International Study. International Journal of $O p$ erations \& Production Management, 26, 24-49. https://doi.org/10.1108/01443570610637003

[4] Hameri, A.-P. and Hintsa, J. (2009) Assessing the Drivers of Change for CrossBorder Supply Chains. International Journal of Physical Distribution \& Logistics Management, 39, 741-761. https://doi.org/10.1108/09600030911008184

[5] Hintsa, J., Gutierrez, X., Wieser, P. and Hameri, A.-P. (2009) Supply Chain Security Management: An Overview. International Journal of Logistics Systems and Management, 5, 344-355. https://doi.org/10.1504/IJLSM.2009.022501

[6] Rao, S. and Goldsby, T.J. (2009) Supply Chain Risks: A Review and Typology. The International Journal of Logistics Management, 20, 97-123.

https://doi.org/10.1108/09574090910954864

[7] Yang, C.C. and Wei, H.H. (2013) The Effect of Supply Chain Security Management on Security Performance in Container Shipping Operations. Supply Chain Management, An International Journal, 18, 74-85. https://doi.org/10.1108/13598541311293195

[8] Tseng, P.-H. and Liao, C.-H. (2015) Supply Chain Integration, Information Technology, Market Orientation and Firm Performance in Container Shipping Firms. The International Journal of Logistics Management, 26, 82-106. https://doi.org/10.1108/IJLM-09-2012-0088

[9] Emirates Airlines, Annual Report (2015). http://cdn.ek.aero/downloads/ek/pdfs/report/annual_report_2015.pdf

[10] Al-Shboul, M. and Alsharari, N. (2018) The Dynamic Behavior of Evolving Efficiency: Evidence from the UAE Stock Markets. The Quarterly Review of Economics and Finance.

[11] Sheffi, Y. (2001) Supply Chain Management under the Threat of International Terrorism. The International Journal of Logistics management, 12, 1-11. https://doi.org/10.1108/09574090110806262

[12] Christopher, M. and Towill, D.R. (2002) Developing Market Specific Supply Chain Strategies. The International Journal of Logistics Management, 13, 1-14. https://doi.org/10.1108/09574090210806324

[13] Closs, D.J. and Savitskie, K. (2003) Internal and External Logistics Information 
Technology Integration. The International Journal of Logistics Management, 14, 63-76. https://doi.org/10.1108/09574090310806549

[14] Lam, J.S.L. and Van De Voorde, E. (2011) Scenario Analysis for Supply Chain Integration in Container Shipping. Maritime Policy \& Management, 38, 705-725. https://doi.org/10.1080/03088839.2011.625988

[15] Altamony, H., Alshurideh, M. and Obeidat, B. (2012) Information Systems for Competitive Advantage: Implementation of an Organisational Strategic Management Process. Proceedings of the 18th IBIMA Conference on Innovation and Sustainable Economic Competitive Advantage: From Regional Development to World Economic, 583-592.

[16] Parvatiyar, A. and Sheth, J.N. (2001) Customer Relationship Management: Emerging Practice, Process, and Discipline. Journal of Economic and Social Research, 3, 1-34.

[17] Alshurideh, M.T. (2014) A Qualitative Analysis of Customer Repeat Purchase Behaviour in the UK Mobile Phone Market. Journal of Management Research, 6, 109-125.

[18] Alshurideh, M.T. (2016) Exploring the Main Factors Affecting Consumer Choice of Mobile Phone Service Provider Contracts. International Journal of Communications, Network and System Sciences, 9, 563-582.

[19] Al Dmour, H., Alshurideh, M. and Shishan, F. (2014) The Influence of Mobile Application Quality and Attributes on the Continuance Intention of Mobile Shopping. Life Science Journal, 11, 172-181.

[20] Alshurideh, M.T. (2016) Is Customer Retention Beneficial for Customers: A Conceptual Background. Journal of Research in Marketing, 5, 382-389.

[21] Alshurideh, M. (2016) Scope of Customer Retention Problem in the Mobile Phone Sector: A Theoretical Perspective. Journal of Marketing and Consumer Research, 20, 64-69.

[22] Nataraja, S. and Al-Aali, A. (2011) The Exceptional Performance Strategies of Emirate Airlines. Competitiveness Review, 21, 471-486.

https://doi.org/10.1108/10595421111171966

[23] Romano, P. (2003) Co-Ordination and Integration Mechanisms to Manage Logistics Processes across Supply Networks. Journal of Purchasing and Supply Management, 9, 119-134. https://doi.org/10.1016/S1478-4092(03)00008-6

[24] Stank, T.P. and Daugherty, P.J. (1997) The Impact of Operating Environment on the Formation of Cooperative Logistics Relationships. Transportation Research Part E: Logistics and Transportation Review, 33, 53-65. https://doi.org/10.1016/S1366-5545(96)00005-1

[25] McGinnis, M.A. and Kohn, J.W. (1990) A Factor Analytic Study of Logistics Strategy. Journal of Business Logistics, 11, 41.

[26] Stock, G.N., Greis, N.P. and Kasarda, J.D. (1998) Logistics, Strategy and Structure: A Conceptual Framework. International Journal of Operations \& Production Management, 18, 37-52. https://doi.org/10.1108/01443579810192772

[27] Stock, G.N., Greis, N.P. and Kasarda, J.D. (2000) Enterprise Logistics and Supply Chain Structure: The Role of Fit. Journal of Operations Management, 18, 531-547. https://doi.org/10.1016/S0272-6963(00)00035-8

[28] Pagell, M. (2004) Understanding the Factors That Enable and Inhibit the Integration of Operations, Purchasing and Logistics. Journal of Operations Management, 22, 459-487. https://doi.org/10.1016/j.jom.2004.05.008 
[29] Flynn, B.B., Huo, B. and Zhao, X. (2010) The Impact of Supply Chain Integration on Performance: A Contingency and Configuration Approach. Journal of Operations Management, 28, 58-71. https://doi.org/10.1016/j.jom.2009.06.001

[30] Yang, C.-S. (2016) The Antecedents and Consequences of Supply Chain Service Capabilities in the Context of Container Shipping. The International Journal of Logistics Management, 27, 236-262. https://doi.org/10.1108/IJLM-09-2014-0151

[31] Heaver, T.D. (2002) The Evolving Roles of Shipping Lines in International Logistics. International Journal of Maritime Economics, 4, 210-230. https://doi.org/10.1057/palgrave.ijme.9100042

[32] Panayides, P.M. and Cullinane, K. (2002) Competitive Advantage in Liner Shipping: A Review and Research Agenda. International Journal of Maritime Economics, 4, 189-209. https://doi.org/10.1057/palgrave.ijme.9100045

[33] Panayides, P. (2006) Enhancing Innovation Capability through Relationship Management and Implications for Performance. European Journal of Innovation Management, 9, 466-483. https://doi.org/10.1108/14601060610707876

[34] Mentzer, J.T., DeWitt, W., Keebler, J.S., Min, S., Nix, N.W., Smith, C.D. and Zacharia, Z.G. (2001) Defining Supply Chain Management. Journal of Business Logistics, 22, 1-25. https://doi.org/10.1002/j.2158-1592.2001.tb00001.x

[35] Van der Vaart, T. and Van Donk, D.P. (2004) Buyer Focus: Evaluation of a New Concept for Supply Chain Integration. International Journal of Production Economics, 92, 21-30. https://doi.org/10.1016/j.ijpe.2003.10.002

[36] Van der Vaart, T. and van Donk, D.P. (2008) A Critical Review of Survey-Based Research in Supply Chain Integration. International Journal of Production Economics, 111, 42-55. https://doi.org/10.1016/j.ijpe.2006.10.011

[37] Vijayasarathy, L.R. (2010) Supply Integration: An Investigation of Its Multi-Dimensionality and Relational Antecedents. International Journal of Production Economics, 124, 489-505. https://doi.org/10.1016/j.ijpe.2010.01.010

[38] Huo, B. (2012) The Impact of Supply Chain Integration on Company Performance: An Organizational Capability Perspective. Supply Chain Management, an International Journal, 17, 596-610. https://doi.org/10.1108/13598541211269210

[39] Bowersox, D. (1989) Logistics in the Integrated Enterprises. Annual Conference of the Council of Logistics Management, St. Louis.

[40] Lasyoud, A.A. and Alsharari, N.M. (2017) Towards an Understanding of the Dimensions and Factors of Management Accounting Change. Asia-Pacific Management Accounting Journal, 12, 105-142.

[41] Kumar, V. (2010) Customer Relationship Management.

[42] Buttle, F. (2009) Customer Relationship Management: Concepts and Technologies. Routledge, Abingdon-on-Thames.

[43] Dwyer, F.R., Schurr, P.H. and Oh, S. (1987) Developing Buyer-Seller Relationships. The Journal of Marketing, 51, 11-27. https://doi.org/10.1177/002224298705100202

[44] Storbacka, K. (2000) Customer Profitability: Analysis and Design Issues. In: Handbook of Relationship Marketing, Sage Publications, Thousand Oaks, 565-586. https://doi.org/10.4135/9781452231310.n21

[45] Dyche, J. (2002) The CRM Handbook: A Business Guide to Customer Relationship Management. Addison-Wesley Professional, Boston.

[46] Akhavan, P. (2012) Application of Knowledge Management in Customer Relationship Management: A Data Mining Approach. http://ssrn.com/abstract=2188230

[47] Sheth, J.N. and Parvatlyar, A. (1995) Relationship Marketing in Consumer Markets: 
Antecedents and Consequences. Journal of the Academy of Marketing Science, 23, 255-271. https://doi.org/10.1177/009207039502300405

[48] Sheth, J.N., Sisodia, R.S. and Sharma, A. (2000) The Antecedents and Consequences of Customer-Centric Marketing. Journal of the Academy of Marketing Science, 28, 55-66. https://doi.org/10.1177/0092070300281006

[49] ELSamen, A.A. and Alshurideh, M. (2012) The Impact of Internal Marketing on Internal Service Quality: A Case Study in a Jordanian Pharmaceutical Company. International Journal of Business and Management, 7, 84-95.

[50] Alshraideh, A.T.R., Al-Lozi, M. and Alshurideh, M.T. (2017) The Impact of Training Strategy on Organizational Loyalty via the Mediating Variables of Organizational Satisfaction and Organizational Performance: An Empirical Study on Jordanian Agricultural Credit Corporation Staff. Journal of Social Sciences, 6, 383-394.

[51] Peppers, D., Rogers, M. and Dorf, B. (1999) Is Your Company Ready for One-toOne Marketing. Harvard Business Review, 77, 151-160.

[52] Iriana, R. and Buttle, F. (2007) Strategic, Operational, and Analytical Customer Relationship Management: Attributes and Measures. Journal of Relationship Marketing, 5, 23-42. https://doi.org/10.1300/J366v05n04_03

[53] Alshurideh, M.T. (2017) A Theoretical Perspective of Contract and Contractual Customer-Supplier Relationship in the Mobile Phone Service Sector. International Journal of Business and Management, 12, 201-210. https://doi.org/10.5539/ijbm.v12n7p201

[54] Kracklauer, A.H., Mills, D.Q. and Seifert, D. (2004) Collaborative Customer Relationship Management: Taking CRM to the Next Level. Springer Science \& Business Media, Berlin.

[55] Borys, B. and Jemison, D.B. (1989) Hybrid Arrangements as Strategic Alliances: Theoretical Issues in Organizational Combinations. Academy of Management Review, 14, 234-249. https://doi.org/10.5465/amr.1989.4282106

[56] Evans, J.R. and Laskin, R.L. (1994) The Relationship Marketing Process: A Conceptualization and Application. Industrial Marketing Management, 23, 439-452. https://doi.org/10.1016/0019-8501(94)90007-8

[57] Alshurideh, M., Nicholson, M. and Xiao, S. (2012) The Effect of Previous Experience on Mobile Subscribers' Repeat Purchase Behaviour. European Journal of Social Sciences, 30, 366-376.

[58] Alshurideh, M., Masa'deh, R. and Alkurdi, B. (2012) The Effect of Customer Satisfaction upon Customer Retention in the Jordanian Mobile Market: An Empirical Investigation. European Journal of Economics, Finance and Administrative Sciences, 47, 69-78.

[59] Alshurideh, M. (2014) The Factors Predicting Students' Satisfaction with Universities' Healthcare Clinics' Services: A Case-Study from the Jordanian Higher Education Sector. Dirasat: Administrative Sciences, 41, 451-464.

[60] Al-dweeri, R.M., Obeidat, Z.M., Al-dwiry, M.A., Alshurideh, M.T. and Alhorani, A.M. (2017) The Impact of e-Service Quality and e-Loyalty on Online Shopping: Moderating Effect of e-Satisfaction and e-Trust. International Journal of Marketing Studies, 9, 92-103.

[61] Alshurideh, M.T., Al-Hawary, S.I.S., Mohammad, A.M.E., Al-Hawary, A.A. and Al Kurdi, B.H. (2017) The Impact of Islamic Banks' Service Quality Perception on Jordanian Customers Loyalty. Journal of Management Research, 9, 139-159.

[62] Chen, I.J. (2001) Planning for ERP Systems: Analysis and Future Trend. Business Process Management Journal, 7, 374-386. 
https://doi.org/10.1108/14637150110406768

[63] Alsharari, N.M. (2017) The Development of Accounting Education and Practice in an Environment of Socio-Economic Transformation in the Middle East: The Case of Jordan. International Journal of Educational Management, 31, 736-751. https://doi.org/10.1108/IJEM-04-2016-0082

[64] Chen, I.J. and Popovich, K. (2003) Understanding Customer Relationship Management (CRM) People, Process and Technology. Business Process Management Journal, 9, 672-688. https://doi.org/10.1108/14637150310496758

[65] Sweat, J. (2000) Oracle Rolls Out Business-Intelligence Products. Information Week, 784, 28-28.

[66] Alsharari, N.M. (2016) The Diffusion of Accounting Innovations in the New Public Sector as Influenced by IMF Reforms: Actor-Network Theory. International Journal of Actor-Network Theory and Technological Innovation, 8, 26-51. https://doi.org/10.4018/IJANTTI.2016100103

[67] Scannell, T. (1999) CRM Looms on the Horizon. Computer Reseller News, 850, 59-60.

[68] Solomon, M. (2000) Like ERP, CRM Systems Can Be a Struggle to Launch. Computerworld, 34, 51.

[69] Saunders, J. (1999) Manufacturers Build on CRM. Computing Canada, 25, 17-18.

[70] Alsharari, N.M., Dixon, R. and Youssef, M.A.E.A. (2015) Management Accounting Change: Critical Review and a New Contextual Framework. Journal of Accounting \& Organizational Change, 11, 476-502. https://doi.org/10.1108/JAOC-05-2014-0030

[71] Yin, R.K. (2003) Case study Research: Design and Methods. Sage Publications, Thousand Oaks.

[72] Almotairi, M. (2009) A Framework for Successful CRM Implementation. European and Mediterranean Conference on Information Systems, Izmir, 13-14 July 2009, $1-14$.

[73] Brignall, S. and Modell, S. (2000) An Institutional Perspective on Performance Measurement and Management in the New Public Sector. Management Accounting Research, 11, 281-306. https://doi.org/10.1006/mare.2000.0136

[74] Lind, J. (2001) Control in World Class Manufacturing-A Longitudinal Case Study. Management Accounting Research, 12, 41-74. https://doi.org/10.1006/mare.2000.0148

[75] Marginson, D.E.W. (2002) Management Control Systems and Their Effects on Strategy Formation at Middle-Management Levels: Evidence from a UK Organization. Strategic Management Journal, 23, 1019-1031. https://doi.org/10.1002/smj.271

[76] Vaivio, J. and Sirén, A. (2010) Insights into Method Triangulation and Paradigms in Interpretive Management Accounting Research. Management Accounting Research, 21, 130-141. https://doi.org/10.1016/j.mar.2010.03.001

[77] Roberts, C.W. (1997) Text Analysis for the Social Sciences: Methods for Drawing Statistical Inferences from Texts and Transcripts. Lawrence Erlbaum Holstein, Mahwah.

[78] Roberts, C.W. (1997) Text Analysis for the Social Sciences: Methods for Drawing Statistical Inferences from Texts and Transcripts. Lawrence Erlbaum Associates, Mahwah.

[79] Silverman, D. (2006) Interpreting Qualitative Data: Methods for Analyzing Talk, Text and Interaction. Sage, Thousand Oaks.

[80] Alshurideh, M. (2010) Customer Service Retention-A Behavioural Perspective of 
the UK Mobile Market. Doctoral Dissertation, Durham University, Durham.

[81] Gill, P., Stewart, K., Treasure, E. and Chadwick, B. (2008) Methods of Data Collection in Qualitative Research: Interviews and Focus Groups. British Dental Journal, 204, 291-295. https://doi.org/10.1038/bdj.2008.192

[82] Ghannajeh, A.M., AlShurideh, M., Zu'bi, M.F., Abuhamad, A., Rumman, G.A., Suifan, T. and Akhorshaideh, A.H.O. (2015) A Qualitative Analysis of Product Innovation in Jordan's Pharmaceutical Sector. European Scientific Journal, 11, 474-503.

[83] Nicholson, M., Clarke, I. and Blakwmore, M. (2002) One Brand, Three Ways to Shop: Situational Variables and Multichannel Consumer Behaviour. The International Review of Retail, Distribution and Consumer Research, 12, 131-148. https://doi.org/10.1080/09593960210127691

[84] AL Kurdi, B. (2016) Healthy-Food Choice and Purchasing Behaviour Analysis: An Exploratory Study of Families in the UK. Doctoral Dissertation, Durham University, Durham.

[85] Alsharari, N.M. (2018) Internationalization of the Higher Education System: An Interpretive Analysis. International Journal of Educational Management, 32, 359 381. https://doi.org/10.1108/IJEM-04-2017-0082

[86] Alsharari, N.M. (2018) Multilevel Institutional Analysis of Accounting Change in Public Management. International Journal of Organizational Analysis, 26, 91-106. https://doi.org/10.1108/IJOA-05-2017-1161

[87] Alsharari, N.M. and Youssef, M.A.E.A. (2017) Management Accounting Change and the Implementation of GFMIS: A Jordanian Case Study. Asian Review of Accounting, 25, 242-261. https://doi.org/10.1108/ARA-06-2016-0062

[88] Alsharari, N.M. and Abougamos, H. (2017) The Processes of Accounting Changes as Emerging from Public and Fiscal Reforms: An Interpretive Study. Asian Review of Accounting, 25, 2-33. https://doi.org/10.1108/ARA-01-2016-0007

[89] Alshurideh, M., Al Kurdi, B.H., Vij, A., Obiedat, Z. and Naser, A. (2016) Marketing Ethics and Relationship Marketing-An Empirical Study that Measure the Effect of Ethics Practices Application on Maintaining Relationships with Customers. International Business Research, 9, 78-90.

[90] Alshurideh, M., Al Kurdi, B., Abu Hussien, A. and Alshaar, H. (2017) Determining the Main Factors Affecting Consumers' Acceptance of Ethical Advertising: A Review of the Jordanian Market. Journal of Marketing Communications, 23, 513-532.

[91] Emirates Airlines (2016) Annual Report. http://cdn.ek.aero/downloads/ek/pdfs/report/annual_report_2016.pdf

[92] Alshurideh, M., Bataineh, A., Alkurdi, B. and Alasmr, N. (2015) Factors Affect Mobile Phone Brand Choices-Studying the Case of Jordan Universities Students. International Business Research, 8, 141-155. https://doi.org/10.5539/ibr.v8n3p141 